\title{
Good Government Governance, Pengendalian Intern, Komitmen Organisasi, Gaya Kepemimpinan dan Kinerja Organisasi Perangkat Daerah
}

\author{
Putu Yoga Ananta Pratyaksa ${ }^{1}$ \\ Fakultas Ekonomi dan Bisnis \\ Universitas Udayana, Indonesia
}

\author{
Ni Gusti Putu Wirawati² \\ Fakultas Ekonomi dan Bisnis \\ Universitas Udayana, Indonesia
}

\begin{abstract}
Surel : anantayoga321@gmail.com
\section{ABSTRAK}

Penerapan prinsip-prinsip Good Government Governance, pengendalian intern, komitmen organisasi, dan gaya kepemimpinan sangat penting dalam pengelolaan organisasi. Penelitian ini bertujuan untuk memperoleh bukti empiris pengaruh Good Government Governance, pengendalian intren, komitmen organisasi, dan gaya kepemimpinan terhadap kinerja organisasi perangkat daerah (OPD) di Kabupaten Karangasem. Penelitian ini menggunakan pendekatan kuantitatif dengan menggunakan data primer. Metode penentuan sampel menggunakan teknik sampling jenuh. Sampel yang digunakan berjumlah 3 orang pegawai di setiap organisasi perangkat daerah (OPD) yang total jumlah yang ada 32 (OPD). Teknik analisis yang digunakan dalam penelitian ini adalah analisis regresi linier berganda. Berdasarkan hasil penelitian ini menunjukkan bahwa pengaruh Good Government Governance, pengendalian intern, komitmen organisasi, dan gaya kepemimpinan berpengaruh positif terhadap kinerja organisasi OPD Kabupaten Karangasem.
\end{abstract}

Kata Kunci: Good Government Governance; Pengendalian Internal; Komitmen Organisasi; Gaya Kepemimpinan Kinerja Organisasi.

Good Government Governance, Internal Control, Organizational Commitment, Leadership Style and Regional Apparatus Organizational Performance

\section{ABSTRACT}

The application of the principles of Good Government Governance, internal control, organizational commitment, and leadership style is very important in organizational management. This study aims to obtain empirical evidence of the effect of Good Government Governance, intellectual control, organizational commitment, and leadership style on the performance of regional apparatus organizations (OPD) in Karangasem Regency. This study uses a quantitative approach using primary data. The sampling method used was saturated sampling technique. The sample used is 3 employees in each regional apparatus organization (OPD) with a total of $32(\mathrm{OPD})$. The analysis technique used in this research is multiple linear regression analysis. Based on the results of this study, it shows that the influence of Good Government Governance, internal control, organizational commitment, and leadership style has a positive effect on the organizational performance of OPD Karangasem Regency.

Keywords: Good Government Governance; Internal Control; Organizational Commitment; Organizational Performance Leadership Style.

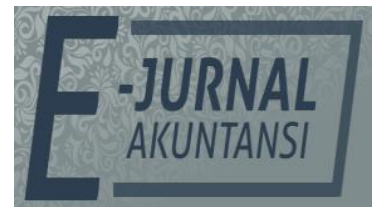

e-ISSN 2302-8556

Vol. 31 No. 3

Denpasar, Maret 2021

Hal. 746-755

DOI:

10.24843/EJA.2021.v31.i03.p17

PENGUTIPAN:

Pratyaksa, P.Y.A., \&

Wirawati, N.G.P. (2021).

Good Government Governance,

Pengendalian Intern, Komitmen Organisasi, Gaya Kepemimpinan dan Kinerja Organisasi Perangkat Daerah. E-Jurnal Akuntansi, 31(3), 746-755

RIWAYAT ARTIKEL: Artikel Masuk:

2 Juli 2020

Artikel Diterima: 10 Maret 2021

Artikel dapat diakses : https://ojs.unud.ac.id/index.php/Akuntansi/index 


\section{PENDAHULUAN}

Peran seorang pegawai sangat penting yang membantu dalam perkembangan instansi, jika telah melaksanakan tugas-tugasnya dengan baik dan benar maka hal tersebut akan berpengaruh terhadap kinerja dari organisasi. Kinerja yang lebih tinggi mengandung arti terjadinya peningkatan efisiensi, efektivitas, atau kualitas yang lebih tinggi dari penyelesaian serangkaian tugas yang dibebankan kepada seorang pegawai dalam suatu organisasi. Faktor kinerja Organisasi Perangkat Daerah (OPD) sangat penting untuk diperhatiakan, karena keberlangsungan dan suksesnya suatu organisasi ditentukan oleh kinerja yang dimiliki dari Organisasi Perangkat Daerah (OPD). Secara umum, kinerja Organisasi Perangkat Daerah (OPD) diyakini dipengaruhi oleh Good Government Governance, pengendalian intern dan komitmen organisasi dan gaya kepemimpinan dari Organisasi Perangkat Daerah (OPD) itu sendiri, pada akhirnya kinerja tersebut akan berdampak pada kinerja Organisasi Perangkat Daerah (OPD).

Perekonomian yang di miliki Indonesia merupakan ekonomi berbasis pasar, dimana pemerintah yang memiliki peranan terpenting. System ekonomi di Indonesia merupakan system yang berdasarkan dari aturan-aturan, aspek dan mekanisme yang di memiliki ketergantungan satu sama lainnya sebagai penglokasian sumber daya milik Negara kepada seluruh masyarakat dengan adil dan merata. Kasus yang terjadi pada Kabupaten Karangasem yaitu mengembalikan yang kerugian Negara senilai Rp. 129.656.403,00. Selain itu, berdasar pemutakhiran data dan pemantauan tindak lanjut atas pemeriksaan BPK Perwakilan Bali tercatat temuan kasus pengelolaan keuangan oleh Pembab Karangasem selama periode 2007-2014 serta bpk mengeluarkan rekomendasi 567 item senilai Rp. 10.506.056.323,00. Dari jumlah itu, karangasem telah menuntaskan tindak lanjut temuan audit itu sebanyak 488 item rekomendasi dengan mengembalikan keuangan Negara senilai Rp 2.997.097.823,00 (http://www.antarabali.com diakses tanggal 8 maret 2015), sehingga Pemkab Karangasem dalam mengelola keuangan Negara tidak pernah mendapat opini Wajar Tanpa Pengecualian (WTP) dari BPK. Jika diandingkan dalam kasus diatas, Inspektorat Karangasem dapat dikatakan belum mampu maksimal dalam mencegah terjadinya penyimpangan/kecurangan penyajian laporan keuangan, karena lemahnya pengawasan dalam penyelanggaran pemerintah daerah setempat, sehingga menyebabkan merosotnya kepercayaan masyarakat khususnya masyarakat keuangan. Oleh karena itu, penelitian termotivasi untuk melakukan penelitian ini karena cukup penting untuk mengetahui factor - factor apa aja yang mempengaruhi pencegahan dan pendeteksi kecurangan penyajian laporan keuangan. Selain itu juga untuk mengetahui seberapa besar variable independen mempengaruhi vaariabel dependen (Apriajana,2014).

Good Government Governance yakni penyelenggaraan tata kelola pemerintahan negara yang bersih atau pemerintahan yang baik. Istilah Good Government Governance (GGG) sangat akrab kita dengar baik itu di kampus dan penerapannya di kalangan instansi. Menurut pendapat (Ambarwati et al, 2013) menyatakan bahwa organisasi yang menerapkan praktek Good Government Governance telah berupaya meminimalkan risiko keputusan yang salah atau yang 
menguntungkan diri sendiri, sehingga meningkatkan kinerja pemerintahan. Sehingga dapat memajukan pemerintahan Kabupaten karangasem.

Good Government Governance memiliki prinsip-prinsip tata kelola pemerintahan yang baik yaitu partisipasi masyarakat, tegaknya supremasi hukum, transparansi, peduli pada stakeholder, berorientasi pada konsensus, kesetaraan, efektifitas dan efisiensi, akuntanbilitas dan visi strategis. Selain itu menurut Aisyah(2014) menyebutkan bahwa dengan melaksanakan Good Government Governance, salah satu manfaat yang bisa dipetik adalah meningkatkan kinerja melalui tercapainya proses pengambilan keputusan yang lebih baik, meningkatkan efisiensi operasional serta lebih meningkatkan pelayanan kepada publik.

Berdasarkan uraian diatas dapat disebutkan bahwa Good Government Governance akan tercapai apabila prinsip-prinsip Good Government Governance dapat terlaksana dengan baik. Penelitian tentang Good Government Governance memberikan bukti empiris bahwa variabel Good Government Governance merupakan faktor penting yang berpengaruh terhadap kinerja Organisasi Perangkat Daerah (OPD) (Setyawan dan Putri, 2013). Dengan demikian, ada pengaruh pelaksanaan prinsip-prinsip Good Government Governance terhadap efektivitas kerja Organisasi Perangkat Daerah (OPD).

Hal lain yang mempengaruhi kinerja Organisasi Perangkat Daerah (OPD) adalah pengendalian intern. Pengendalian intern akuntansi yang berfungsi untuk mengatur teknik akuntansi seperti perubahan dalam pendekatan sistem akuntansi dan prosedur pencatatan, dokumen dan formulir yang digunakan, fungsi-fungsi otorisasi untuk tujuan pengendalian intern, laporan serta pengawasan. Pengendalian intern merupakan hal yang mempengaruhi kualitas laporan keuangan (Sari, 2014). Fungsi pengendalian intern tersebut dapat membantu sumber daya manusia untuk mengetahui batasan-batasan dan hakhak dalam bekerja serta teknologi informasi seperti apa yang bisa dimanfaatkan untuk membantu pekerjaannya tersebut. Dengan pengendalian intern yang baik maka pemerintah akan dapat menghasilkan laporan keuangan yang berkualitas.

Pengendalian intern terdiri dari 5 (lima) komponen, yaitu lingkungan pengendalian, penilaian risiko, aktivitas pengendalian dan informasi dan komunikasi serta pemantauan. Pelaksanaan sistem pengendalian intern seharusnya bertumpu pada penguatan sistem pengendalian yang sudah terbangun dan dilaksanakan oleh seluruh faktor dalam organisasi mulai dari adanya kebijakan, pembentukan organisasi, penyiapan anggaran, sarana dan prasarana, penetapan personil yang melaksanakan, penetapan prosedur dan review pada seluruh tahapan. Dengan adanya pengedalian intern maka seluruh proses kegiatan audit, review, evaluasi, pemantauan dan kegiatan pengawasan lain terhadap organisasi dalam rangka memberikan keyakinan yang memadai bahwa kegiatan telah dilaksanakan sesuai dengan tolak ukur yang telah ditetapkan secara efektif dan efisiensi untuk kepentingan pimpinan dalam mewujudkan tata kelola kepemerintahan yang baik. Oleh karena itu diharapkan dengan sistem pengendalian intern yang efektif akan berpengaruh terhadap kinerja manajerial Organisasi Perangkat Daerah (OPD). Untuk memperbaiki kinerja pemerintah perlu diciptakannya sistem pengendalian intern pemerintah 
agar instansi pemerintah dapat mengetahui dana publik yang digunakan oleh pemerintah pusat dan pemerintah daerah.

Selain sistem pengendalian intern, komitmen organisasi di nilai juga berpengaruh pada terciptanya kinerja sektor publik yang baik. komitmen organisasi adalah sejauh mana seorang pegawai mengidentifikasi dengan organisasi tertentu dan tujuannya dan keinginan untuk mempertahankan keanggotaan dalam organisasi (Robbin \& Judge, 2008). Pegawai yang memiliki komitmen organisasi yang tinggi akan menunjukka kinerja yang baik.

Selain good governance dan sistem pengendalian intern pemerintah, gaya kepemimpinan juga berpengaruh terhadap kinerja. Gaya kepimpinan (leadership style) juga berperan penting dalam meningkatkan kinerja. Gaya pemimpinan merupakan cara pemimpin untuk mempengaruhi orang lain atau bawahanya sedemikian rupa sehingga orang tersebut mau melakukan kehendak pemimpin untuk mencapai tujuan organisasi meskipun secara pribadi hal resebut mungkin tidak disenangi (Elya Wati, 2010). Pemimpin merupakan pemain utama yang menetukan berhasil atau tidaknya suatu organisasi. Pemimpin dapat memberikan pengaruh dalam menanamkan disiplin bekerja para anggota organisasi untuk meningkatkan kinerjanya. Gaya kepemimpinan juga dapat mempengaruhi kreatifitas kinerja dalam melaksanakan tugasnya sebagai anggota organisasi. Elya Wati (2010) menyatakan bahwa gaya kepemimpinan berpengaruh positif terhadap kinerja organisasi perangkat daerah OPD.

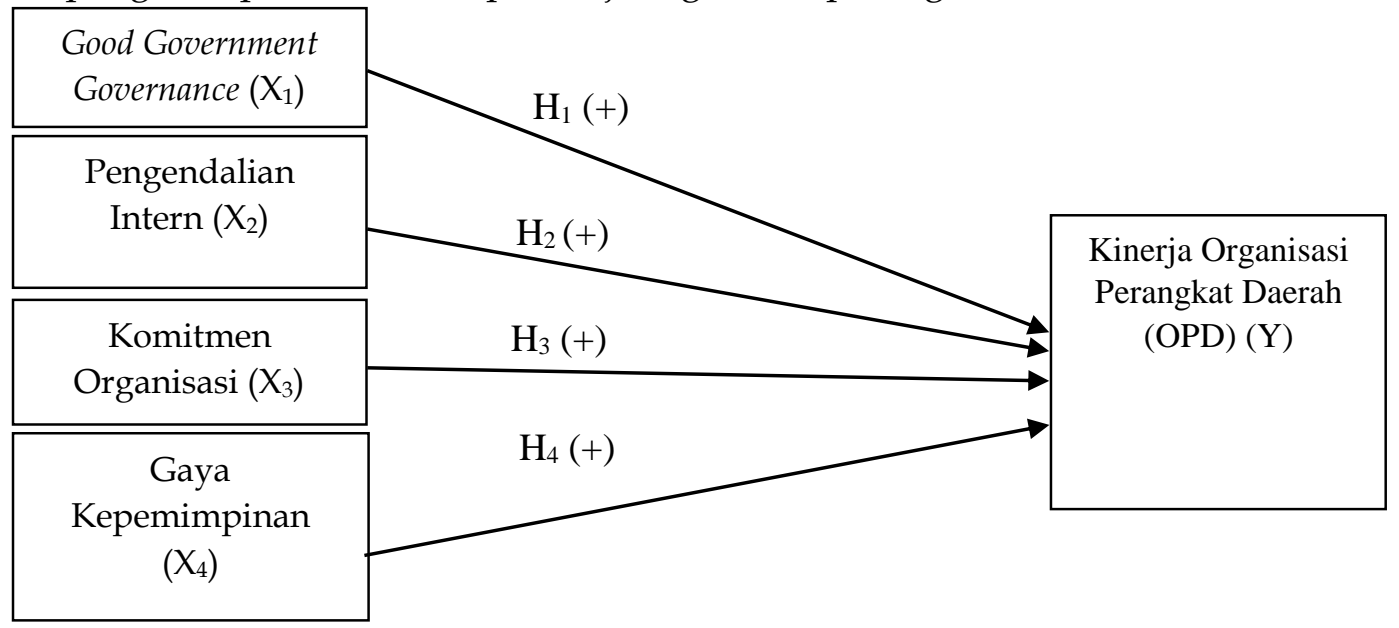

Sumber: Data Penelitian, 2019

\section{METODE PENELITIAN}

Penelitian ini menggunakan pendekatan kuantitatif yang bersifat asosiatif. Pendekatan kuantitatif adalah metode penelitian yang digunakan untuk meneliti populasi atau sampel tertentu yang bertujuan untuk menguji hipotesis yang telah ditetapkan (Sugiyono, 2013:13). Penelitian berbentuk asosiatif adalah penelitian yang bertujuan untuk mengetahui hubungan antara dua variabel atau lebih (Sugiyono, 2013:13). Penelitian ini menjelaskan pengaruh Good Government Governance, pengendalian intern, komitmen organisasi dan gaya kepemimpinan terhadap kinerja Organisasi Perangkat Daerah (OPD). Variabel bebas dalam penelitian ini adalah yang terdiri dari Good Government Governance (X1) 
pengendalian intern (X2) komitmen organisasi $(X 3)$ gaya kepemimpinan $(X 4)$ sementara variabel terikat $(Y)$ dalam penelitian ini adalah kinerjaOrganisasi Perangkat Daerah (OPD) di Kabupaten Karangasem.

Metode pengumpulan data yang digunakan dalam penelitian ini adalah dengan menggunakan kuesioner. Kuesioner merupakan metode pengumpulan data yang dilakukan dengan cara memberi seperangkat pertanyaan atau penyataan yang terkait dengan penelitian secara tertulis kepada responden penelitian untuk dijawab (Sugiyono, 2013:199). Kuesioner yang digunakan dalam penelitian ini digunakan untuk mengukur variabel Good Government Governance, pengendalian intern, komitmen organisasi, gaya kepemimpinan dan kinerja Organisasi Perangkat Daerah (OPD) yang diadopsi dari penelitian Putri (2017).

Metode penentuan sampel yang digunakan dalam penelitian ini adalah teknik sampling jenuh. Teknik sampling jenuh adalah teknik penentuan sampel bila semua anggota populasi digunakan sebagai sampel (Sugiyono, 2014:124). Oleh sebab itu penelitian ini mengambil jumlah sampel sebanyak 3 (tiga) pegawai. Adapun yang menjadi kriteria responden dalam penelitian adalah kepala bagian keuangan dan dua staf pegawai bagian keuangan yang bekerja pada Organisasi Perangkat Daerah (OPD) di Kabupaten Karangasem. Pengujian dilakukan meggunakan alat analisis regresi linier berganda dengan model sebagai berikut.

$Y=a+\beta 1 X 1+\beta 2 X 2+\beta 3 X 3+\beta 4 X 4+\varepsilon$

Keterangan :

\begin{tabular}{|c|c|}
\hline XI & = Good Government Governance \\
\hline $\mathrm{X} 2$ & $=$ Pengendalian Intern \\
\hline $\mathrm{X} 3$ & $=$ komitmen Organisasi \\
\hline X4 & = Gaya kepemimpinan \\
\hline Y & $=$ Kinerja Organisasi Perangkat Daerah $(\mathrm{OPD})$ \\
\hline a & $=$ Konstanta \\
\hline$\beta 1, \beta 2, \beta 3, \beta 4, \beta 5$ & $=$ Koefisien regresi untuk $\mathrm{X} 1, \mathrm{X} 2, \mathrm{X} 3, \mathrm{X} 4$ \\
\hline
\end{tabular}

\section{HASIL DAN PEMBAHASAN}

Responden yang dipilih dalam penelitian ini adalah 3 orang. Pegawai kepala bagian keuangan dan dua staf pegawai bagian keuangan di masing-masing Organisasi Perangkat Daerah (OPD) Kabupaten Karangasem yang dijadikan sampel. Berdasarkan kriteria yang ditetapkan maka sampel diambil sebanyak 96 orang yang berkerja di bagian keuangan dari 32 jumlah keseluruhan Organisasi Perangkat Daerah (OPD) Kabupaten Karangasem.

Karakteristik responden berdasarkan jenis kelamin dapat digunakan untuk mengetahui proporsi responden laki-laki dan perempuan pada Organisasi Perangkat Daerah (OPD) Kabupaten Karangasem. Pada Tabel 2, menunjukkan bahwa jumlah responden laki-laki sebanyak 47 orang (49\%) dan jumlah responden perempuan sebanyak 49 orang (51\%). Hal ini menunjukkan bahwa mayoritas responden adalah perempuan. Karakteristik responden berdasarkan usianya digunakan untuk mengetahui rentang usia pegawai yang bekerja pada Organisasi Perangkat Daerah (OPD) Kabupaten Karangasem. Tabel 2 menunjukkan bahwa responden yang berusia 21 sampai 27 tahun sebanyak 1 
orang (1\%), usia 28 sampai 34 tahun sebanyak 5 orang (5.2\%), usia 35 sampai 41 tahun sebanyak 25 orang $(26.2 \%)$, usia 42 sampai 48 tahun sebanyak 26 orang (27.1\%), usia 49 sampai 54 tahun sebanyak 30 orang (31.2\%) dan usia 55 sampai 57 tahun sebanyak 9 orang $(9.3 \%)$. Hal ini menunjukkan bahwa mayoritas responden berusia 49 sampai 55 tahun. Karakteristik responden berdasarkan tingkat pendidikan terakhir digunakan sebagai indikator untuk mengetahui tingkat pendidikan yang ditempuh oleh responden pada Organisasi Perangkat Daerah (OPD) Kabupaten Karangasem. Tabel 2, menunjukkan bahwa responden yang memiliki tingkat pendidikan pada jenjang SMA / SMK sebanyak 11 orang (11.5\%), pada jenjang D3 sebanyak 1 orang (1\%), pada jenjang S1 sebanyak 69 orang $(71.8 \%)$, dan responden yang memiliki pendidikan pada jenjang S2 sebanyak 15 orang $(15.7 \%)$. Hal ini menunjukkan bahwa berdasarkan tingkat pendidikan terakhir yang mendominasi adalah responden dengan tingkat pendidikan S1. Karakteristik responden berdasarkan lama bekerja digunakan sebagai indikator untuk mengetahui pengalaman responden dalam bekerja pada Organisasi Perangkat Daerah (OPD) Kabupaten Karangasem. Tabel 2, menunjukkan bahwa sebanyak 10 orang (10.4\%) yang bekerja antara 1 sampai 5 tahun. Sebanyak 18 orang (18.3\%) yang bekerja selama 6 sampai 10 tahun, dan 68 orang $(70.3 \%)$ yang bekerja selama lebih dari 10 tahun. Hal ini menunjukkan bahwa mayoritas responden telah bekerja selama lebih dari 10 tahun.

\section{Tabel 2. Karakteristik Responden}

\begin{tabular}{|c|c|c|c|}
\hline No. & Karakteristik & Jumlah & Persentase $(\%)$ \\
\hline \multirow[t]{4}{*}{1} & Jenis Kelamin: & & \\
\hline & Pria & 47 & 49 \\
\hline & Wanita & 49 & 51 \\
\hline & Total & 96 & 100 \\
\hline \multirow[t]{8}{*}{2} & Umur: & & \\
\hline & 21-27 Tahun & 1 & 1 \\
\hline & 28-34 Tahun & 5 & 5.2 \\
\hline & 35-41 Tahun & 25 & 26.2 \\
\hline & 42-48 Tahun & 26 & 27.1 \\
\hline & 49-54 Tahun & 30 & 31.2 \\
\hline & 55-57 Tahun & 9 & 9.3 \\
\hline & Total & 96 & 100 \\
\hline \multirow[t]{7}{*}{3} & Tingkat Pendidikan: & & \\
\hline & SMA / SMK & 11 & 11.5 \\
\hline & D3 & 1 & 1 \\
\hline & S1 & 69 & 71.8 \\
\hline & S2 & 15 & 15.7 \\
\hline & S3 & - & - \\
\hline & Total & 96 & 100 \\
\hline \multirow[t]{6}{*}{4} & Pengalaman Kerja: & & \\
\hline & $<1$ tahun & - & - \\
\hline & $1-5$ tahun & 10 & 10.4 \\
\hline & $6-10$ tahun & 18 & 18.3 \\
\hline & $>10$ tahun & 68 & 70.3 \\
\hline & Total & 96 & 100 \\
\hline
\end{tabular}

Sumber: Data Penelitian,2020 
Berdasarkan hasil analisis regresi linier berganda seperti yang disajikan pada Tabel 3, maka dapat dibuat persamaan regresi sebagai berikut.

$$
Y=1,865+0,104 X 1+0,269 \text { X2 + 0,167 X3 + 0,233 X4 }
$$

Nilai signifikansi masing-masing variabel bebas kurang dari 0,05. Hal ini menunjukkan bahwa semua variabel bebas memiliki pengaruh yang signifikan terhadap variabel terikat. Berdasarkan hasil persamaan ini, dapat dijelaskan pola pengaruh Good Goverment Governance, pengendalian internal, komitmen organisasi, dan gaya kepemimpinan sebagai berikut.

Tabel 2. Hasil Regresi Linear Berganda

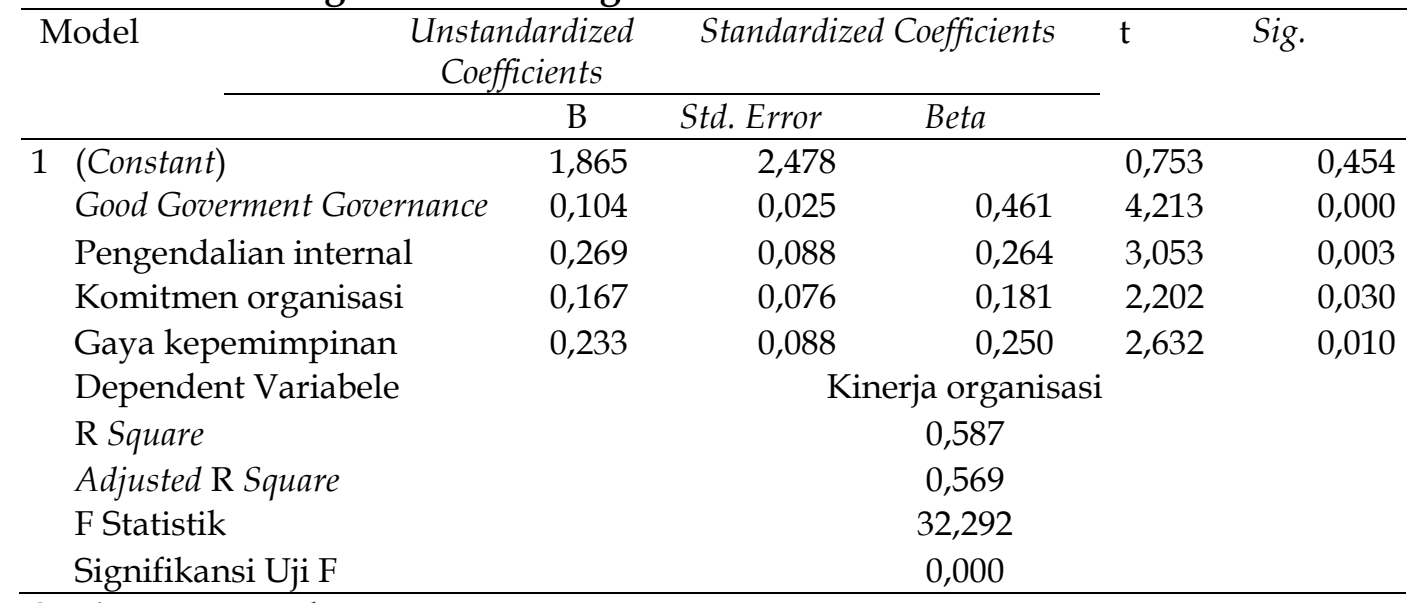

Sumber: Data Penelitian,2020

Koefisien regresi Good Goverment Governance ( $\beta 1$ ) sebesar 0,104 berarti apabila Good Goverment Governance (X1) dinaikkan satu satuan dan variabel lainya tidak berubah maka kinerja organisasi (Y) naik sebesar 0,104 satuan, artinya setiap peningkatan Good Goverment Governance dapat meningkatkan kinerja organisasi, (2) Koefisien regresi pengendalian internal ( $\beta 2)$ sebesar 0,269 berarti apabila pengendalian internal (X2) dinaikkan satu satuan dan variabel lainya tidak berubah maka kinerja organisasi $(Y)$ naik sebesar 0,269 satuan, artinya setiap peningkatan pengendalian internal dapat meningkatkan kinerja organisasi, (3) Koefisien regresi komitmen organisasi ( $\beta 3$ ) sebesar 0,167 berarti apabila komitmen organisasi (X3) dinaikkan satu satuan dan variabel lainya tidak berubah maka kinerja organisasi (Y) naik sebesar 0,167 satuan, artinya setiap peningkatan komitmen organisasi dapat meningkatkan kinerja organisasi, (4) Koefisien regresi gaya kepemimpinan $(\beta 4)$ sebesar 0,233 berarti apabila gaya kepemimpinan (X4) dinaikkan satu satuan dan variabel lainya tidak berubah maka kinerja organisasi $(Y)$ naik sebesar 0,233 satuan, artinya setiap peningkatan gaya kepemimpinan dapat meningkatkan kinerja organisasi.

\section{SIMPULAN}

Berdasarkan hasil analisis dan uraian sebelumnya, maka dapat diperoleh simpulan bahwa Good Government Governance berpengaruh positif terhadap efektivitas kinerja Pemerintah Daerah Kabupaten Karangasem. Pengendalian Intern berpengaruh positif terhadap efektivitas kinerja Pemerintah Daerah Kabupaten Karangasem. Komitmen Organisasi berpengaruh positif terhadap efektivitas kinerja Pemerintah Daerah Kabupaten Karangasem. Gaya 
Kepemimpinan berpengaruh positif terhadap efektivitas kinerja Pemerintah Daerah Kabupaten Karangasem.

Organisasi Perangkat Daerah (OPD) yang ada di Kabupaten Karangasem dimana dalam penelitian ini menggunakan sampel seluruh Organisasi Perangakat Daerah (OPD) Kabupaten Karangasem yang berjumalah 32 diharapkan terus meningkatkan efektivitas kinerjanya di Instansinya masingmasing, karena dengan adanya Good Government Governance yang efektif diharapkan dapat meminimalkan kecurangan-kecurangan yang mungkin timbul dalam suatu instansi seperti praktik korupsi, pengelolan pendapatan dan pengelolaan belanja yang tidak sesuai ketentuan, yang dapat menimbulkan kerugian bagi daerah tersebut. Organisasi Perangkat Daerah (OPD) Kabupaten Karangasem diharapkan terus mengevaluasi kinerja pegawainya agar dapat memberikan pelayanan publik yang terbaik dan memuaskan masyarakat serta dapat meningkatkan kinerja instansi di Kabupaten Karangasem. Pimpinan OPD harusnya lebih mengawasi dan memonitoring pegawai agar tingkat kinerja yang di berikan pegawai lebih baik, Penelitian ini tidak lepas dari beberapa kelemahan maka untuk penelitian selanjutnya sebaiknya melakukan penambahan faktor eksternal lain diluar variabel yang sudah digunakan dalam penelitian ini untuk mendapatkan hasil yang lebih lengkap dan mencerminkan kondisi sesungguhnya.

\section{REFERENSI}

Aisyah, Siti. Karmizi \& Safitri, Eni. (2014). Pengaruh Good Governance, Gaya Kepemimpinan, Komitmen Organisasi dan Budaya Organisasi Terhadap Kinerja Pemerintah Daerah (Studi pada Pemerintah Daerah Kabupaten). Jurnal Online Mahasiswa Fakultas Ekonomi Universitas Riau, 1(2).

Ambarwati, (2013). Analisis Pengaruh Penerapan Prinsip-Prinsip Good Corporate Governance Dan Komitmen Organisasi Terhadap Kinerja Aparatur Pemerintahan (Studi Empiris pada Instansi-Instandi dan Satuan Kerja Perangkat Daerah Kabupaten Banyumas). Jurnal SNA XV1. Universitas Jendral Soedirman.

Aprijana, A. A. G. R., Adiputra, I. M. P., Ari. N., \& Darmawan, S. (2014). Pengaruh Pemahaman Good Governance Dan Keahlian Kecurangan Penyajian Laporan Keuangan (Studi Empiris pada Inspektorat Pemerintahan Kabupaten Buleleng dan Inspektorat Pemerintahan Kabupaten Karangasem). 2

Budiarti, I., \& Bank, P. (2010). Penerapan prinsip - prinsip Good Corporate Governance pada Dunia Perbangkan. Jurnal Manajemen Vol.8, No. 2. 8(2), 263-269.

Claraini, C. (2017). Pengaruh Good Governence, system Pengendalian Intern Pemerintah dan Gaya Kepemimpinan Terhadap Kinerja Pemerintah Daerah. Jurnal Akuntansi. JOM fekon, Vol 4 no.1

Company, P., Jensen, C., \& Meckling, H. (1976). Theory Of The Firm : Managerial Behavior , Agency Costs And Ownership Structure I ., 305-360.

Dewi, Krismaya Kadek \& Putri, IGAM Asri Dwija (2014). Pengaruh Penerapan Prinsip-Prinsip Good Corporate Governance pada Kinerja Pegawai Lembaga 
Perkreditan Desa Kabupaten Gianyar Bali. E-Jurnal Akuntansi Universitas Udayana 7(3):h:559-573.

Fauziah, Shifa (2016). Analisis Pengaruh Penerapan Prinsip-Prinsip Good Corporate Governance, Motivasi dan Budaya Organisasi terhadap Kinerja Aparatur Pemerintahan. Jurnal Fakultas Ekonomi Universitas Muhammadiyah Surakarta.

Ghozali, H. Imam (2012). Aplikasi Analisis Multivariate Dengan Program IBM SPSS. Edisi Enam. Semarang: Universitas Diponegoro.

Hasibuan, Malayu (2003). Manajemen Sumber Daya Manusia. Edisi Revisi. Jakarta: PT. Bumi Aksara.

Kanfer \& Ackerman (1989). Dalam Pridarsanti dan Yuyetta (2013) Fuziah, Shifa dan , Dra. Rina Trisnawati, Ak, M.Si, Ph.D (2016) Analisis Pengaruh Penerapan Prinsip-Prinsip Good Corporate Governance, Motivasi dan Budaya Organisasi terhadap Kinerja Aparatur Pemerintahan (Studi Empiris Pada Satuan Kerja Perangkat Daerah Kota Surakarta). Tesis, Universitas Muhammadiyah Surakarta.

Karmila, (2012). Pengaruh Kapasitas Sumber Daya Manusia dan Sistem Pengendalian Intern terhadap Keterandalan Pelaporan Keuangan Pemerintah Daerah (Studi Empiris Pada Pemerintah Kabupaten Riau). Jurnal Sorot. Vol. 9 No.1.

Komite Nasional Kebijakan Governance (KNKG). (2006). Pedoman Umum Good Corporate governance Indonesia, Jakarta.

Mardiasmo, (2002). Akuntansi Sektor Publik. Yogyakarta: Andi.

Nasution, M., \& Setiawan, D. (2007). Pengaruh Corporate Governance terhadap Manajemen Laba di Industri Perbankan Indonesia. Simposium Nasional Akuntansi X.

Ni Luh Putu Andriyani Pratiwi dan I Gusti Ayu Made Asri Dwija Putri. (2016). Pengaruh Good Corporate Governance Pada Kinerja Berbasis Balanced Scorecard. E-Jurnal Akuntansi. Vol.15.2. Mei : 832-846

Peraturan Pemerintah, (2008). Sistem Pengendalian Intern Pemerintah. PP Nomor 60 Tahun 2008.

Pratolo, Suryo. (2010). Peran Good Government Governance Untuk Mewujudkan Kinerja Pemerintahan Daerah dan Kepuasan Masyarakat di Era Otonomi Daerah dalam Menghadapi Tantangan Global (Studi pada Pemerintah Kabupaten dan Kota di Daerah Istimewa Yogyakarta). Simposium Riset Ekonomi IV.

Putri, IGAM Asri Dwija. (2012). Peranan Good Corporate Governance dan Budaya terhadap Kinerja Organisasi. Jurnal Ilmiah Akuntansi dan Bisnis. Vol. 7 No 2

Putri, IGAM Asri Dwija. (2015). Sumber Daya Manusia, Good Corporate Governance, Dan Kinerja Perusahaan. Jurnal Ilmiah Akuntansi dan Bisnis. Vol XI No 1

Robbins, (2006). Prinsip-prinsip Perlaku Organisasi, Edisi Kelima, Erlangga, Jakarta h:123.

Setiyawati, H. (2013). The effect of Internal Accountants ' Competence , Managers ' Commitment to Organizations and the Implementation of the Internal Control System on the Quality of Financial Reporting. 2(11), 19-27. 
Setyawan, K. M., \& Dwija Putri, I GAM. (2013). Pengaruh Good Corporate Governance terhadap Kinerja Pegawai Lembaga Pekreditan Desa di Kecamatan Mengwi Kabupaten Badung. E-Jurnal Akuntansi. 5(3): h:586598.

Shifa Fauzan. (2016). Analisis Pengaruh Penerapan Prinsip-Prinsip Good Corporate Governance, Motivasi dan Budaya Organisasi terhadap Kinerja Aparatur Pemerintahan.

Stephen P. Robbins Dan Mary Coulter. (2010). Manajemen. Edisi 10. Jakarta: Erlangga H:64.

Sugandi, Joe. (2013). Pengaruh Kapasitas Sumber Daya Manusia, Pemanfaatan Teknologi Informasi, Pengendalian Intern Akuntansi, dan Komitmen Organisasi Terhadap Keterandalan Pelaporan Keuangan Pemerintah Daerah (Survei Pada SKPD se-Kabupaten Kuansing). Jurnal Akuntansi. Universitas Riau.

Suryana, Cut Erna et al. (2015). Pengaruh Komitmen, Kompetensi, Motivasi dan Budaya Organisasi terhadap Kepuasan Kerja Serta Dampaknya pada Kinerja Pegawai Badan Kesatuan Bangsa Politik dan Perlindungan Masyarakat Aceh. Jurnal Magister Manajemen Program Pascasarjana Universitas Syiah Kuala Banda Aceh ISSN 2302-0199 pp. 29-38.

Yudhasena, I. G. I., Asri, I. G. A. M., \& Putri, D. (2019). Pengaruh Good Government Governance, Pengendalian Intern, dan Budaya Organisasi Terhadap Kinerja Organisasi Perangkat Daerah (OPD). E-Jurnal Akuntansi. $28,434-464$.

Zeyn, E. (2011). Pengaruh Good Governance dan Standar Akuntansi Pemerintahan Terhadap Akuntabilitas Keuangan Dengan Komitmen Organisasi Sebagai Pemoderasi. Jurnal Reviu Akuntansi Dan Keuangan. Vol.1 No. 1, April 2011, Pp 21-37 